\title{
Approaches to the Evaluation of Thermal-hygric Microclimatic Conditions in Selected Manufacturing Organizations
}

\author{
Miriam Andrejiová', Ružena Králiková2, Miriama Piňosová2 ${ }^{*}$, Miroslav Rusko³ \\ 1 Technical University of Košice, Faculty of Mechanical Engineering, Department of Applied Mathematics and \\ Informatics, Letná 1/9, 04200 Košice, Slovakia \\ 2 Technical University of Košice, Faculty of Mechanical Engineering, Department of Process and Environmental \\ Engineering, P. Komenského 53/5, 04001 Košice, Slovakia \\ 3 Slovak University of Technology in Bratislava, Faculty of Materials Science and Technology in Trnava, \\ Department of Safety Engineering, Jána Bottu 2781/25, 91724 Trnava, Slovakia \\ * Corresponding author's e-mail: m.p.tuke@gmail.com
}

\begin{abstract}
Attention was paid to the theoretical and empirical aspects of the evaluation of the thermal-hygric microclimate parameters of the working environment and their impact on the employees. The evaluation included questionnaire research, which involved two main areas: 1 . Thermal-hygric microclimate conditions in the workplace; 2 . Health problems of employees related to workplace conditions. The research was participated in by 200 employees working in manufacturing mechanical engineering organizations. The entry criterion for inclusion in the data set was the good health of the respondent, not suffering from serious health problems. The results of the evaluation showed that there is a statistically significant dependence between some of the monitored characteristics: between the age of the employee and the occurrence of monitored health problems (headache, feeling cold, spine pain), as well as between the work done and the satisfaction with the humidity of the workplace or with a feeling of dry nasal mucosa. The results of the questionnaire survey also showed a significant dependence between the type of manufacturing organization and the thermal and humidity conditions in the workplace or the occurrence of respondents' health problems. In addition, a moderately positive relationship was found between thermal-hygric microclimatic conditions and the feeling of fatigue and headaches (or feeling of cold symptoms, spinal pain, and dry nasal mucous membrane). When evaluating the questionnaire research, statistical methods were used to monitor categorical dependence.
\end{abstract}

Keywords: thermal-hygric microclimate, risk evaluations, workplaces, health problems

\section{INTRODUCTION}

The industrial revolution, which began in 1760 , was connected not only with the massive development of industrial activities, the emergence and development of new technologies, processes and production processes, but also with the deterioration of the quality of the working environment, resulting in negative impacts on the health of employees at work. For decades, no or little attention was paid to the working conditions of employees. The deterioration of the state of health has been attributed to natural ageing and has rarely been linked to inappropriate working conditions.

Today's competitive environment requires not only competitive technological equipment and efficient, cheaper and more stable processes, but also an emphasis on the third pillar of the production process, i.e. the workers themselves. Experienced and highly satisfied worker (the knowledge worker) once again plays an important role in the production process. Appropriate workplace conditions "well-being" are indispensable for a production, as workers are the most valuable resource of the enterprise, which is still true, at of 
today's high automation, and at the onset of the so-called "4th industrial revolution".

The employees' health protection must be ensured above all, because workplace comfort is affecting not only a health, but also a productivity of employees.

Notwithstanding the fact that health protection at work is set by law ISO 45001:2018 (formerly OHSAS 18001) [1] its role is played by the above-mentioned employee satisfaction and their impact on labour productivity must be respected and appropriate precautions should be taken to avoid adverse effects $[2 \div 5]$

Despite significant progress in this area, we are still confronted with a tolerant approach to health protection. It is not easy to see if a specific work environment is characterized by a quality that has no or only minimal impact on health. Simple measurement of selected work environment factors is often not sufficient to reliably identify impacts on employee health at work. Therefore, it is necessary to understand the impact of individual factors on health and know methods and procedures to objectively measure the impact of these factors as well as methods for an overall assessment of the effects of conditions of the working environment on human health.

The industrial work environment is generally affected by one or more undesirable influences [6]. The subject of this research is the mechanical engineering working environment nature of as determined primarily by the place in which the manufacturing process takes place and technical equipment, which is a significant source of heat, or cold, it is characterized by increased dustiness and humidity, temperature fluctuations etc., to which the employees are exposed during their work.

The thermal-hygric microclimate is part of the overall microclimate of the working environment $[7,8]$. Jokl, in his paper states that the thermal-hygric microclimate is a component of the environment formed by flows of heat and humidity flows - heat and water vapour, to which the person is exposed and together affect its overall state $[9 \div 11]$. According to $[12,13]$ the factors of the thermal-hygric microclimate such as excessive heat or cold, damp (water vapour), improper air flow are considered harmful. The thermalhygric microclimate factors, under certain conditions, if their values are high or low, may pose a health risk to employees [14]. Jirák also states in his work that thermal-hygric conditions in the workplace affect not only the working welfare of the employees but they also have a major impact on the productivity of the work and the safety of the employees. It rightly states that every employer should naturally try to provide optimal thermal and humidity working conditions if at least a little is possible [15].

Factors which are undesirable and damaging to health in the industrial work environment are defined as physical, chemical and biological factors that can cause health problems. The longterm maintenance of capacity to work and corresponding performance at work, together with the need to preserve health at work, requires an active approach labelled with the term health support [16].

When considering the thermal-hygric microclimate in a working environment, it is necessary to take into consideration the following aspects: 1) Although it is possible to qualify and quantify each of the partial factors, the thermal-hygric microclimate is a complex of quantities and their interaction; 2) The importance of exposure time, i.e. the time period during which a person is exposed to thermal-hygric microclimate factors and the type of work activity; 3) Different people's reactions to the same values of the same factor may vary; 4) The effects of thermal-hygric microclimate may be somewhat "mitigated" by the adaptation or acclimatization of a person [17].

The branch of hygiene, which deals with the investigation of the impact of the work process on human health and the determination of the requirements for the creation of conditions for health protection at work, is occupational hygiene. It is a system of organizational, health and medical-technical measures that prevent or reduce the impact of harmful factors in the working environment [18]. The duty of employers is to create optimal thermal and humidity microclimate conditions in the workplace so that the employee can feel thermal comfort during the performance of his work. Thermal comfort means that temperatures are reached where a person does not feel cold or too warm, and feels comfortable [19, 20]. Thermal comfort is the condition of the mind that expresses satisfaction with the temperature and which is based on subjective evaluation $[21 \div 23]$. Its disturbance threatens the balanced temperature state of the human organism, which is a basic condition of its existence [24]. 


\section{CURRENT SITUATION IN SLOVAKIA}

The issue of the thermal-hygric microclimate (THM) is addressed in Slovakia by several decrees, government regulations and several STN standards (taken from international standards). The objectivization of the physical quantities of the thermal and humidity microclimate is carried out following the Professional Guideline of the Ministry of Health of the Slovak Republic [25], which regulates the procedure for the measurement and assessment of the thermal-hygric microclimate. In order to assess the fulfilment of thermal-hygric microclimate requirements at work, the basis is the results of direct or indirect measurement and their comparison with the values of

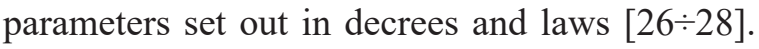
In accordance with decrees the thermal-hygric microclimate is part of the overall microclimate of the working environment and its most important factors are the air temperature $\left(\mathrm{t}_{\mathrm{a}}\right)$, the mean radiant temperature $\left(t_{r, m}\right)$, the relative air humidity $\left(r_{h}\right)$, the air flow velocity $\left(v_{a}\right)$ and the stereo temperature $\left(\mathrm{t}_{\mathrm{st}}\right)$, which are made objective by measurement and established the limit values for determining the parameters of the thermal-hygric microclimate for individual types of work depending on the thermal production of the organism during the performance of the work activity.

It is clear from the laws and regulations that the permissible values of the factors of the thermalhygric microclimate must not be exceeded in the workplace. In order to meet these requirements, preventive measures are applied, including techni-

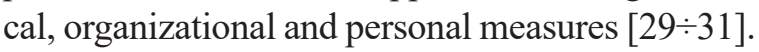
Technical measures are aimed at eliminating the health hazards of the working environment and the exposure of employees to their action so as not to endanger the health of working people. Organizational measures aim at reducing exposure to risk factors to the shortest possible time, adjusting workflows. Personal measures are aimed at the use of personal protective equipment when technical and organizational measures can not provide working conditions that do not pose a health risk.

\section{METODOLOGY OF RESEARCH}

The assessment of the thermal-hygric microclimatic conditions of the working environment requires comparison of the established facts with the requirements of the standards and the hygienic regulations and decrees, or finding the satisfaction / dissatisfaction with the comfort of the working environment on the part of the employees. During objectification of the physical factors of the thermal-hygric microclimate by measurement, current methodologies and measuring techniques are used. Objective methods consist of the measurement of thermal-hygric parameters and physiological responses of humans to the defined environment. The evaluation is performed on the basis of the comparison of the measured variables with the optimal, allowed limits. If the measured values of a factor exceed standard values, it is important to ensure that the factor is eliminated by applying different measures [32]. The strategy of risk assessment for prevention of stress or discomfort in mild, cold and hot working conditions is addressed in STN EN ISO 15265: 2005-07 (83 3557) [33]. Subjective assessment methods are most often performed on the basis of a questionnaire survey to determine the subjective perception of the factor acting on the tested subject / person.

The evaluation of the heat and humidity microclimate conditions in the selected workplaces of the manufacturing (mechanical engineering) organizations included a questionnaire survey, in which we were interested in two main areas: 1.) Heat and humidity microclimate conditions in the workplace (satisfaction with humidity, temperature and air flow at the workplace, need for increased humidity and air temperature); 2.) Workplace health problems for employees (feeling of fatigue during working hours, symptoms of spinal pain, headache, feeling cold symptoms, dry nasal mucous membranes). Additional questions included information that provided us with more details about the gender, age and health status of the respondents, the type of work performed, the workplace drinking regimen, employees' work clothes, and so on.

Respondents subjectively evaluated the thermal and humidity microclimatic conditions and health problems on an evaluation scale as follows: "never = 1"; "occasionally / rarely $=2$ "; "often = 3"; "very often / almost always $=4$ ". To determine the interdependence between selected category symbols, Pearson's chi-squared test was used. The assessment of the closeness of the determined dependence between the category characters was performed using the contingency coefficient $\Phi$. Relationships between selected items of subjective evaluation were also expressed using the Pearson correlation coefficient [34, 35]. 


\section{RESULTS OF QUESTIONNAIRE SURVEY}

The results of this research are based on a questionnaire survey that was conducted in the spring season of the year (namely March, April and May). In this part of the study, important elements of the research will be presented, providing information on its character, the sample of respondents, the method of data acquisition and the way data was processed.

\section{Basic research data}

The survey sample was made up of employees who met all of our conditions. The sample set was 200 employees (respondents) from five manufacturing organizations aged $23-60$. The average age of respondents who participated in the research was approximately 33 years. $129(64.5 \%)$ men and $71(35.5 \%)$ women were surveyed. In the age category up to 24 years old there were 71 respondents (35.5\%), 67 respondents $(33.5 \%)$ were aged 25-34 years old. In the age group 35-44 there were 48 respondents $(24.0 \%)$ and 14 respondents $(7.0 \%)$ were aged 45 and over.

Up to 192 respondents $(96.0 \%)$ said they did not suffer from serious illnesses. Only $8(4.0 \%)$ of them said they were in a poor state of health and suffered from a serious illness. In further research, we only continued with respondents who said their health was good. There were 123 men $(64.1 \%)$ and 69 women $(35.9 \%)$ in the sample of 192 respondents.

Respondents were asked about their length of service in the given workplace and the type of working clothes they are provided with for their work. Appropriate workwear for staff is an essential part of working in unsuitable thermal-hygric conditions. When working in the cold, the thermal insulation of an employee is of utmost importance, i.e. protective clothing. Suitable clothing prevents the wind and moisture penetrating to the skin while enabling sweating and capturing sweat. Acclimatization to the cold is of great importance, i.e. the gradual prolonging of the stay in the cold working environment. Prevention includes instruction in using protective clothing and personal protective equipment, as well as recognizing early symptoms of general and local hypothermia and providing first aid. When working in excessive heat, technical measures such as reducing the intensity of the heat source, removing the source (mechanical apertures, barriers), local employee cooling (air or water showers), general ventilation (natural, forced) and organizational measures among which we can include the regime of work and rest (rotation of employees, working breaks in favourable microclimatic conditions, etc.). As many as 183 respondents $(95.3 \%)$ have been working in the workplace for more than six weeks. Only nine respondents $(4.7 \%)$ have been working in the workplace for less than six weeks. Standard workwear is used by 173 respondents (90.1\%), 19 respondents (9.9\%) must have special workwear compulsory for the workplace (e.g. waterproof, logging, welding, anti-static non-flammable clothing, various types of aprons etc.).

We must also remember the drinking regimen of employees. Its goal is to replace the loss of fluid and salt during the working shift so as to avoid unwanted negative health symptoms. Often, or always there is a drinking regimen provided at the workplace for 181 respondents $(94.3 \%)$. According to the amendment to the Act on Health and Safety at Work, every employer must provide a drinking regime at the workplace for all employees according to the internal regulation when exceeding the permissible values of thermal and humidity microclimatic conditions. From the result obtained, we can state that in all organizations monitored this obligation is respected by the employer.

Up to 169 respondents $(88.0 \%)$ may often or always, during breaks, leave the room where they work. The breakdown of respondents by type of work is shown in Table 1.

Respondents who participated in the survey are employees of five manufacturing organizations operating in the mechanical engineering industry in the east of Slovakia. Representation of respondents in organizations is almost the equal: Organization 1 (17.7\%), Organization 2 (20.8\%), Organization 3 (19.9\%), Organization 4 (20.8\%) and Organization $5(20.8 \%)$ of respondents. The representation of men and women is shown in the following table.

\section{Satisfaction with thermal and humidity microclimatic conditions at the workplace}

Drahoš, in his paper, states that setting the boundary of thermal comfort to suit all people is virtually impossible, and therefore a certain percentage of dissatisfied people is always to be expected [36]. 
Table 1. Representation of respondents in each class of work

\begin{tabular}{|c|c|c|c|c|c|}
\hline \multirow{2}{*}{ Respondents } & \multicolumn{4}{|c|}{ Class of work } & \multirow{2}{*}{ Total } \\
\hline & $1 \mathrm{a}$ & $1 \mathrm{c}$ & $2 a$ & 3 & \\
\hline Man & $9(4.7 \%)$ & $79(41.1 \%)$ & $25(13.0 \%)$ & $10(5.2 \%)$ & $123(64.1 \%)$ \\
\hline Woman & $18(9.4 \%)$ & $44(22.9 \%)$ & $7(3.7 \%)$ & $0(0.0 \%)$ & $69(35.9 \%)$ \\
\hline Total & $27(14.1 \%)$ & $123(64.0 \%)$ & $32(16.7 \%)$ & $10(5.2 \%)$ & $192(100.0 \%)$ \\
\hline
\end{tabular}

Explanatory notes: $1 \mathrm{a}$ - work in a position with minimal movement activity, or connected with light manual work with the arms and hands (class of work by total energy expenditure, in the sense of decrees No. 99/2016); $1 \mathrm{c}-$ standing work occasionally connected with slow walking with carrying of light loads up to $10 \mathrm{~kg}$ or overcoming light resistance; $2 \mathrm{a}$ - standing work with constant use of both hands, shoulders and legs, or. work associated with carrying loads up to $15 \mathrm{~kg} ; 3$ - intensive work at a rapid pace associated with carrying loads up to $25 \mathrm{~kg}$.

Table 2. Representation of respondents in individual manufacturing organizations

\begin{tabular}{|l|c|c|c|c|c|}
\hline \multirow{2}{*}{ Respondents } & \multicolumn{5}{|c|}{ Organization } \\
\cline { 2 - 6 } & 1 & 2 & 3 & 4 & 5 \\
\hline Man & $29(85.3 \%)$ & $35(87.5 \%)$ & $28(73.7 \%)$ & $15(37.5 \%)$ & $16(40.0 \%)$ \\
\hline Woman & $5(14.7 \%)$ & $5(12.5 \%)$ & $10(26.3 \%)$ & $25(62.5 \%)$ & $24(60.0 \%)$ \\
\hline Total & $34(100.0 \%)$ & $40(100.0 \%)$ & $38(100.0 \%)$ & $40(100.0 \%)$ & $40(100.0 \%)$ \\
\hline
\end{tabular}

As many as 106 respondents (55.2\%) stated that they were only occasionally or never suited by the humidity in the room where they work. Increased humidity of air was desired sometimes by $115(59.9 \%)$, and often or very often by 50 $(26.0 \%)$ respondents. 127 of the respondents $(66.2 \%)$ said that they never or occasionally were bothered by the set airflow rate in the room. The air temperature in the room was satisfactory often or very often for only 91 people asked (47.4\%). Only very rarely or never was a higher room temperature desired by as many as $187(97.4 \%)$ of respondents. The evaluation of the thermal-hygric microclimatic conditions is given in Table 3 .

Lumnitzer, in his publication, states that the thermal balance of the body and at the same time thermal comfort are influenced by the factors: indoor environment (air temperature, relative humidity of air, radiant effects of surrounding areas, airflow velocity and turbulence), the body exposed (metabolic value, clothing); additional factors (acclimatization to outdoor climate, acclimatization to indoor climate, body and subcutaneous fat, age and gender) [14].

In our case, the overall thermal sensation (B5) corresponding to comfort was evaluated by $56(29.2 \%)$ as warm, $66(34.4 \%)$ as slightly warm, and by $12(6.2 \%)$ respondents as slightly cold-tocold. Up to 58 respondents (30.2\%) evaluated their thermal feeling as neutral. The average score of the thermal sensation corresponding to comfort was 2.15. The intrinsic consistency (reliability) of the subjective assessments of the thermal-hygric microclimatic conditions at the workplace was determined by the Cronbach's alpha coefficient. The value of 0.9 indicates very good reliability.

\section{Appearance of health problems}

During work hours, only 37 (19.3\%) of respondents feel uncomfortable. However, 155 respondents $(80.7 \%)$ occasionally or often feel tired. In $51(26.6 \%)$ of respondents, the effect of air flow never causes local pain in the spine. Occasionally or often spinal pain is experienced by $112(58.3 \%)$, and $29(15.1 \%)$ of respondents respectively. Occasionally, or often 117 (60.9\%) of the respondents suffer from headaches during their working hours. The feeling of cold symptoms is experienced by $135(70.3 \%)$ of the interviewed employees during their working hours. The feeling of dried nasal mucosa during the working time is experienced by $113(58.9 \%)$ respondents and often by 30 respondents (15.6\%). Up to 138 respondents $(71.9 \%)$ stated that inadequate thermal-hygric microclimate conditions in the workplace cause them health problems (see Table 4). The intrinsic consistency of detected health problems was determined by Cronbach's alpha coefficient, where the value of 0.9 indicated very good reliability.

In a warm environment or with rising production of metabolic heat, the human body responds by the widening of the subcutaneous vessels (vasodilatation), thus increasing the supply of subcutaneous blood. This results in an 
Table 3. Thermal-hygric microclimatic conditions at the workplace $(n=192)$

\begin{tabular}{|l|c|c|c|c|c|}
\hline \multicolumn{1}{|c|}{ Scale } & B1 & B2 & B3 & B4 & B5 \\
\hline Never & $10(5.2 \%)$ & $27(14.1 \%)$ & $25(13.1 \%)$ & $7(3.6 \%)$ & $123(64.1 \%)$ \\
\hline Only occasionally & $96(50.0 \%)$ & $115(59.9 \%)$ & $102(53.1 \%)$ & $94(49.0 \%)$ & $64(33.3 \%)$ \\
\hline Often & $74(38.5 \%)$ & $46(23.9 \%)$ & $55(28.6 \%)$ & $75(39.1 \%)$ & $5(2.6 \%)$ \\
\hline Very often & $12(6.3 \%)$ & $4(2.1 \%)$ & $10(5.2 \%)$ & $16(8.3 \%)$ & - \\
\hline Average rating & 2.5 & 2.1 & 2.3 & 2.5 & 1.4 \\
\hline
\end{tabular}

Explanatory notes: B1 - satisfaction with humidity of air, B2 - need for increased humidity, B3 - satisfaction with air flow rate, B4 - air temperature satisfaction, B5 - need to increase air temperature.

Table 4. Respondents' health problems ( $\mathrm{n}=192)$

\begin{tabular}{|l|c|c|c|c|c|}
\hline \multicolumn{1}{|c|}{ Scale } & B7 & B8 & B9 & B10 & B11 \\
\hline Never & $37(19.3 \%)$ & $51(26.6 \%)$ & $75(39.1 \%)$ & $57(29.7 \%)$ & $49(25.5 \%)$ \\
\hline Only occasionally & $119(62.0 \%)$ & $112(58.3 \%)$ & $102(53.1 \%)$ & $120(62.5 \%)$ & $113(58.9 \%)$ \\
\hline Often, very often & $36(18.7 \%)$ & $29(15.1 \%)$ & $15(7.8 \%)$ & $15(7.8 \%)$ & $30(15.6 \%)$ \\
\hline Average rating & 2.0 & 1.9 & 1.7 & 1.8 & 1.9 \\
\hline
\end{tabular}

Explanatory notes: B7 - Feeling fatigue, B8 - Backache, B9 - Headache, B10 - Feeling cold symptoms, B11 - Feeling of dried nasal mucosa.

increase in skin temperature that will increase removal of heat from the body. If the increase in skin temperature cannot restore thermal balance, sweat glands are activated and evaporation cooling begins. However, if these two mechanisms cannot restore the body's thermal balance, the body overheats - hyperthermia. The first health signs of hyperthermia are weakness, headache, nausea, short breathing, accelerated heart rate (up to $150 / \mathrm{min}$.), etc. In heat shock, the temperature rises rapidly over $41^{\circ} \mathrm{C}$, sweating stops, coma starts and death occurs. In a cold environment, the human body first responds by lowering the subcutaneous blood circulation, reducing the temperature of the skin, which consequently reduces heat loss. This process is accompanied by the emergence of goose pimple or the atavistic phenomenon of hairs standing up on the skin, which results in better thermal insulation of the skin. If this mechanism is ineffective, muscle tension begins, shivering which increases the body's thermal output. If these physiological responses do not provide thermal balance, the cooling of the body will occur-hypothermia and the internal temperature may fall below $35^{\circ} \mathrm{C}$. If the temperature of the body begins to fall, the heart rate decreases and there is a disruption of blood circulation, with death occurring at a core temperature between $25^{\circ} \mathrm{C}$ and $30^{\circ} \mathrm{C}$. For these reasons, these health symptoms should not be neglected and great importance should be attached to them.

\section{Test of dependence between selected variables}

In the next part of the study, we studied the relationship between the selected variables $(\alpha=0.05)$. In the assessment, we used the following labelling: Respondent gender (A1), Age category (A2), Type of work performed (A3), Manufacturing organization (A4), Room humidity of air (B1), Satisfaction with air flow in the room (B3), Satisfaction with air temperature (B4), Air temperature increase (B5), Heat sensitivity assessment (B6), Feeling of fatigue (B7), Pain in the spine (B8) headache (B9), feeling of cold symptoms (B10), feeling of dry nasal mucosa (B11) and occurrence of health problems (B12).

First we tested the dependence of two variables: Respondent gender (A1) and satisfaction with microclimatic conditions (B1 to B6), or health problems of respondents (B7 to B12). The results of the Pearson Test revealed dependence between the respondent Gender and Satisfaction with Room Humidity (p-value $=0.047$ ). We used the coefficient $\Phi$ to assess the degree of dependence. The calculated value indicates that it is a weak dependence $(\Phi=0.20)$. On the other hand, dependence of age category and Satisfaction with room air temperature ( $p$-value $=0.294)$ was not confirmed. Pearson's chi-squared test revealed a moderate dependence between respondent gender and satisfaction with air flow in the room (B3). A slight dependence was found, for example, between the respondents' gender and the feeling of 
the dried nasal mucosa (B11), spinal pain (B8), or headache (B9).

Analogously, we determined the dependence of the other three variables A2 to A4 to the variables $\mathrm{B} 1$ to $\mathrm{B} 12$. The results are shown in Tables 5 and 6.

From the Pearson chi-squared test, there was moderate dependence between the age group of respondents (A2) and spinal pain (B8), headache (B9), feeling of chilling (B10) and the occurrence of health problems as a result of inappropriate thermal-hygric microclimatic conditions at the workplace (B12) as well as the moderate dependence between the type of work performed and the need to increase the air temperature (B5) and the feeling of the dried nasal mucosa (B11). Dependence is statistically significant also for the age group of respondents and satisfaction with humidity of air (B1), or with room air temperature (B4). By testing, we found a strong dependence between the type of work performed (A3) and satisfaction with the humidity of air in the room (B1).
When observing the influence of the manufacturing organization (A4) on the selected variables (B1 to B12), there is a statistically significant dependence between all pairs of variables (A4 and BX), where $X=1$ to 12 . From the values of the contingency coefficient $\Phi$ it follows that in most cases it is a moderate dependence.

The study also included the observation of dependence between B1, B3 and B4 and B7 to B11. Test results show that there is a statistically significant dependence between satisfaction with humidity of air in the room (B1) or satisfaction with air flow in the room (B3), and all health problems (fatigue, spinal pain, headache, feeling of cold symptoms, feeling of dry airway mucosa). The contingency coefficient $\Phi$ indicates that there is a mild to medium dependency between the variables (Table 7).

In the case of satisfaction with room air temperature (B4), there was a significant dependence on only one variable, the feeling of cold symptoms (B10). The test results are shown in Table 7.

Table 5. Chi-squared test results

\begin{tabular}{|c|c|c|c|c|c|c|c|c|c|c|c|c|c|}
\hline & ariable & B1 & B2 & B3 & B4 & B5 & B6 & B7 & B8 & B9 & B10 & B11 & B12 \\
\hline \multirow{3}{*}{ A1 } & $\mathrm{Chi}^{2}$-test & 7.95 & 16.59 & 22.34 & 2.16 & 1.98 & 7.27 & 5.63 & 6.21 & 7.08 & 2.34 & 13.75 & 4.71 \\
\hline & $p$-value & 0.04 & $<0.001$ & $<0.001$ & 0.54 & 0.37 & 0.06 & 0.06 & 0.04 & 0.03 & 0.31 & $<0.001$ & 0.09 \\
\hline & $\Phi$ & 0.20 & 0.29 & 0.34 & - & - & - & - & 0.18 & 0.19 & - & 0.27 & - \\
\hline \multirow{3}{*}{ A2 } & Chi²-test & 11.30 & 2.89 & 7.97 & 13.71 & 5.02 & 11.76 & 12.32 & 27.44 & 10.37 & 25.9 & 9.48 & 15.8 \\
\hline & $p$-value & 0.02 & 0.82 & 0.24 & 0.01 & 0.16 & 0.07 & 0.06 & $<0.001$ & 0.03 & $<0.001$ & 0.15 & 0.001 \\
\hline & $\Phi$ & 0.24 & - & - & 0.27 & - & - & - & 0.38 & 0.23 & 0.37 & - & 0.29 \\
\hline \multirow{3}{*}{ A3 } & Chi²-test & 47.3 & 7.91 & 7.10 & 10.80 & 28.31 & 22.30 & 4.10 & 7.05 & 3.69 & 1.47 & 5.82 & 1.41 \\
\hline & $p$-value & 0.001 & 0.24 & 0.31 & 0.10 & $<0.001$ & 0.001 & 0.66 & 0.32 & 0.30 & 0.69 & 0.01 & 0.70 \\
\hline & $\Phi$ & 0.50 & - & - & - & 0.38 & 0.26 & - & - & - & - & 0.34 & - \\
\hline
\end{tabular}

Table 6. Chi-squared test results

\begin{tabular}{|c|c|c|c|c|c|c|c|c|c|c|c|c|c|}
\hline \multicolumn{2}{|c|}{ Variable } & B1 & B2 & B3 & B4 & B5 & B6 & B7 & B8 & B9 & B10 & B11 & B12 \\
\hline \multirow{4}{*}{ A4 } & Chi'-test $^{2}$ & 26.9 & 48.3 & 54.1 & 19.8 & 32.1 & 27.0 & 33.3 & 21.7 & 31.8 & 18.6 & 44.1 & 40.9 \\
\cline { 2 - 40 } & p-value & 0.001 & $<0.001$ & $<0.001$ & 0.01 & $<0.001$ & 0.001 & $<0.001$ & 0.01 & $<0.001$ & 0.02 & $<0.001$ & $<0.001$ \\
\cline { 2 - 14 } & $\Phi$ & 0.37 & 0.50 & 0.53 & 0.32 & 0.41 & 0.38 & 0.42 & 0.34 & 0.41 & 0.31 & 0.48 \\
\hline
\end{tabular}

Table 7. Chi-squared test results

\begin{tabular}{|c|c|c|c|c|c|c|}
\hline & able & B7 & B8 & B9 & B10 & B11 \\
\hline \multirow{3}{*}{ B1 } & Chi²-test & 29.4 & 13.6 & 11.7 & 14.8 & 24.8 \\
\hline & p-value & $<0.001$ & 0.03 & 0.008 & 0.002 & $<0.001$ \\
\hline & $\Phi$ & 0.39 & 0.27 & 0.25 & 0.28 & 0.36 \\
\hline \multirow{3}{*}{ B3 } & $\mathrm{Chi}^{2}$-test & 19.7 & 41.9 & 18.1 & 20.9 & 45.6 \\
\hline & $p$-value & 0.003 & $<0.001$ & $<0.001$ & $<0.001$ & $<0.001$ \\
\hline & $\Phi$ & 0.32 & 0.47 & 0.31 & 0.33 & 0.49 \\
\hline \multirow{3}{*}{ B4 } & Chi²-test & 7.9 & 7.6 & 5.9 & 13.5 & 9.1 \\
\hline & $p$-value & 0.24 & 0.27 & 0.12 & 0.004 & 0.17 \\
\hline & $\Phi$ & - & - & - & 0.27 & - \\
\hline
\end{tabular}


The relationships between the individual items of subjective evaluation are expressed using the Pearson correlation coefficient (Figure 1). In the figure 1, the correlations with $p$-value $<0.01$ are considered as significant. In this case the correlation coefficient values are marked with an asterisk $(*, * *, * * *)$.

From the results stated in the correlation matrix we can assume a positive mean dependency for example between the health effects of the feelings of Fatigue (B7) and Spinal pain (B8) $(r=0.52)$; Fatigue (B7) and Headache (B9) $(\mathrm{r}=0.54)$; Fatigue (B7) and Cold symptoms (B10) $(\mathrm{r}=0.50)$; Headache (B9) and Cold symptoms (B10) $(\mathrm{r}=0.61)$; Cold symptoms (B10) and Feeling of a dried nasal mucosa (B11) ( $\mathrm{r}=0.53)$. In the context of thermal-hygric microclimate conditions in the workplace, there is a slight average dependence between Increased air temperature (B5) and Evaluation of thermal feeling (B6) $(r=0.45)$; and moderate negative dependence between Room humidity satisfaction (B1) and Humidity of air in the room (B2) $(r=-0.56)$. Further mutual relationships are in the correlation matrix.

\section{CONCLUSIONS}

The effect of individual thermal-hygric microclimatic factors on the working environment on human beings and on their health can not be evaluated in isolation, because their mutual combinations can significantly influence, increase or multiply, depending on the work done.

The main objective of this study was to implement, evaluate and analyse a questionnaire survey of the subjective evaluation of the thermal-hygric microclimatic conditions of the working environment in selected manufacturing engineering organizations. It is important to be aware that the lack of appreciation of some of the factors of the thermal-hygric microclimate of the working environment results in a deterioration in working conditions, impairment of employee health, increased fatigue and overall discomfort to the employee, which may increase the risk of injuries. The positive effect of thermal-hygric microclimatic conditions enables increased working capacity of the employee - good health, increased work performance of the employee by reducing the mental

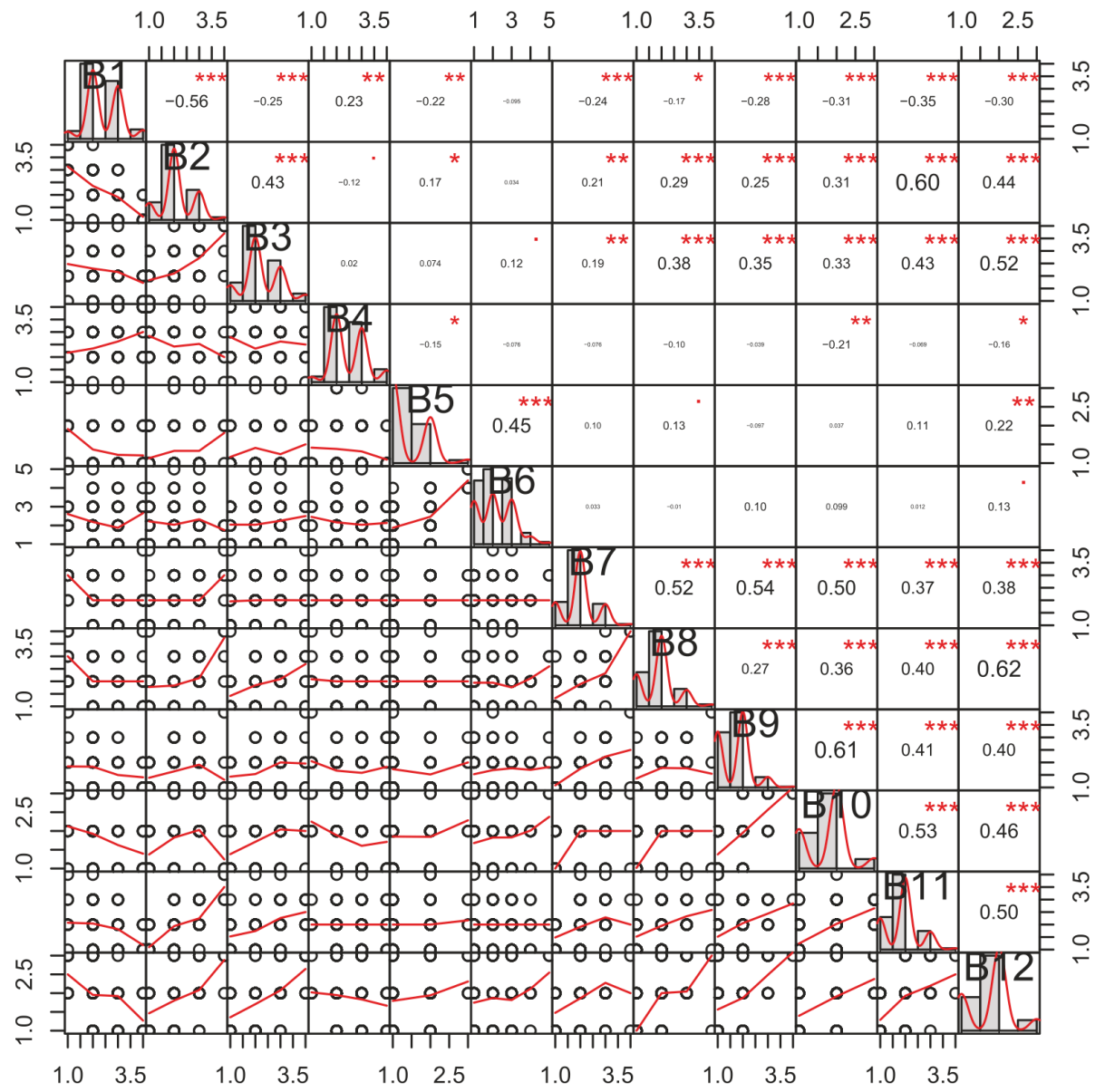

Fig. 1. Correlation matrix 
and physical load, as well as to increase the quality and safety of work performance as well as the health of employees.

The results of questionnaire survey may be a challenge for employers and management of organizations to implement preventive and corrective measures to adhere to the thermal and humidity microclimatic conditions in workplaces that meet the requirements set by legislation, regulations, recommendations or standards.

Suitable conditions at the workplace are essential for production. This is why in many companies they are increasingly focusing on improving working conditions. As the most important source of entrepreneurship, today still in high automation, at the threshold of the so-called $4^{\text {th }}$ Industrial Revolution are the health protection of employees and high quality of the working environment, which must be perfect safeguarded in the future.

The research held at the Technical University of Košice tries to describe and define all aspects of the microclimate conditions at the present-day workshops buildings. The essential contribution of this research is to involve importance of microclimate conditions for human health, safety and productivity. Healthy indoor microclimate is a result of keeping all parameters of microclimate on an optimal level.

Since there have not been paid attention to a comprehensively behaviour of indoor air quality it is essential to monitor in future ones more. To this problems will be oriented the future research it will be especially regarding low-energy buildings as very actual topic.

\section{Acknowledgements}

This paper was written in frame of the work on the projects KEGA 032TUKE-4/2018 (50\%). The Slovak Research and Development Agency supported this work under the contract No. APVV-0327-15 (50\%).

\section{REFERENCES}

1. ISO 45001:2018 Occupational health and safety management systems - Requirements with guidance for use.

2. Jendritzky G., de Dear R., Havenith G. UTCI-Why another thermal index? Int J Biometeorol., 56(3), 2012, 421-428.
3. Karvatte N., Klosowski E.S., de Almeida R.G., Mesquita E.E., de Oliveira C.C., Alves F.V. Shading effect on microclimate and thermal comfort indexes in integrated crop-livestock-forest systems in the Brazilian Midwest. Int J Biometeorol., 60(12), 2016, 1933-41.

4. Mishra A.K., Loomans M.G.L.C., Hensen J.L.M. Thermal comfort of heterogeneous and dynamic indoor conditions - An overview. Build Environ., 109, 2016, 82-100.

5. Song X., Yang L., Zheng W., Ren Y., Lin Y. Analysis on Human Adaptive Levels in Different Kinds of Indoor Thermal Environment. Procedia Engineering., 2015, 151-157.

6. Herczner P., Pauliková A. Koncepcie hodnotenia strojárskych prevádzok. Strojárstvo., 11(11), 2011, 11-2.

7. Andrejiová M., Králiková R. Hodnotenie a analýza vzt'ahov parametrov tepelno-vlhkostnej mikroklímy. Fyzikálne Fakt prostredia., 4(2), 2014, 7-10.

8. Králiková R., Andrejiová M. Stanovenie mikroklimatických parametrov v horúcom pracovnom prostredí. Fyzikálne Fakt prostredia., 1(mimor.), 2011, 196-202.

9. Jokl M.V. Teorie vnitřního prostředí budov. 2nd ed. Praha: Praha: ČVUT; 1993, pp. 216.

10. Jokl M.V. Zdravé obytné a pracovní prostředí. 1st ed. Praha: Praha: Academia; 2002, pp. 261.

11. Jokl M.V. Hodnocení kvality vzduchu v interieru. II. část: Výměna vzduchu pro jeho přípustnou kvalitu. Bezpečná práca., 27(1), 1996, 16-9.

12. Parkinson T., de Dear R. Thermal pleasure in built environments: spatial alliesthesia from air movement. Build Res Inf., 44(3), 2015, 1-16.

13. Yang R., Liu L., Ren Y. Thermal environment in the cotton textile workshop. Energy Build., 102, 2015, 432-441.

14. Lumnitzer E., Piňosová M., Andrejiová M., Hricová B. Metodológia komplexného hodnotenia zdravotných rizík v priemysle 2. 1. vydanie. Zręcin: Zręcin: MUSKA sp. z o.o.; 2013, pp. 326.

15. Jirák Z., Jokl M., Tomášková H., Oleksiaková Z., Benatíková Š., Malý S., et al. Nový přístup $\mathrm{k}$ hodnocení tepelně vlhkostních podmínek na pracovištích. Pr lékařství., 64(1), 2012, 23-31.

16. Tuček M., Cikrt M., Pelclová D. Pracovní lékařství pro praxi: př́ručka $\mathrm{s}$ doporučenými standardy. Praha: Grada Publishing a.s.; 2005, pp. 344.

17. Slamková E., Dulina L., Tabaková M. Ergonómia v priemysle. 1st ed. GEORG; 2010, pp. 262.

18. Kubáni V. Psychológia práce. Prešov: Prešovská univerzita; 2011, pp. 166.

19. Auliciems A., Szokolay S.V. Thermal Comfort. first. Brisbane: The University of Queensland 
Brisbane; 1997, pp. 66.

20. Cihelka J. Vytápění, větrání a klimatizace. Praha: Praha: SNTL; 1985, pp. 648.

21. Brager G., Zhang H., Arens E. Evolving opportunities for providing thermal comfort. Build Res Inf., 43(3), 2015, 274-287.

22. Ashrae. ASHRAE Handbook - Fundamentals (SI Edition). 2005 Ashrae Handbook Fundamentals SI Edition. 2009.

23. ASHRAE. ASHRAE Standard 55-2010: Thermal Environmental Conditions for Human Occupancy. Am Soc Heating, Refrig Air Cond Eng., 2013.

24. Fanger PO. Thermal Comfort: analysis and applications in environmental engineering. Copenhagen: Danish Technical Press; 1970, pp. 244.

25. OdbornéhousmerneniaMZSRč.OOFŽP/268/2013, ktorým sa upravuje postup pri meraní a hodnotení tepelno-vlhkostnej mikroklímy.

26. Zákon č. 103/2015 Z. Z., o ochrane, podpore a rozvoji verejného zdravia a o zmene a doplnení niektorých zákonov.

27. Vyhláška Ministerstva zdravotníctva Slovenskej republiky č. 99/2016 Z.z. o podrobnostiach o ochrane zdravia pred zát’ažou teplom a chladom pri práci.

28. Vyhláška č. 391/2006 Z. z. o minimálnych bezpečnostných a zdravotných požiadavkách na pracovisko.
29. Buchancová J. a kol. Pracovné lekárstvo a toxikológia. 1st ed. Martin: Osveta; 2003, pp. 1132.

30. Fedorko G, Liptai P, Molnar V. Proposal of the methodology for noise sources identification and analysis of continuous transport systems using an acoustic camera. Engineering Failure Analysis., 83(2018), 2018, 30-43.

31. Fedorko F, Husakova N, Dudas G. Design of allocation of new technological equipment within the frame of production process in company Getrag Ford Transmissions Slovakia, s.r.o. Acta Montanistica Slovaca., 15(1), 2010, 14-22.

32. Brager G.S., de Dear R.J. Thermal adaptation in the built environment: a literature review. Energy Build. 27, 1998, 83-96.

33. STN EN ISO 15265:2005-07 (83 3557) Ergonómia tepelného prostredia. Stratégia posudzovania rizika pri prevencii proti stresu alebo nepohodliu v tepelných pracovných podmienkach.

34. Řezanková H. Analýza dat z dotazníkových šetrení. 3rd ed. Praha: Professional Publishing; 2011, pp. 223.

35. Hendl J. Přehled statistických metód. Analýza a metaanalýza dat. 3rd ed. Praha: Portál; 2009, 734 p.

36. Drahoš R, Drahoš M. Zdravotné aspekty tepelnovlhkostnej mikroklímy pri práci. D2R engineering, s.r.o.; Poprad. pp. 9. 